\title{
Strengthening Pupils' Physical Activity through Outdoor Education
}

\author{
Radek Durna, Hana Svobodová
}

\author{
Faculty of Education, Masaryk University
}

\begin{abstract}
:
The time pupils spend at school provides a very small benefit to pupils' movement activity. At a time when many school-age children lack physical activity, it is necessary to think about how to integrate more movement into the period that the child spends at school. The paper is based on the assumption that outdoor education can contribute to the development of movement activity of pupils, and the paper aims to determine to what extent. For model pupils, the calorie count and metabolic discharge, including sedentary analysis, were recorded through an ActiGraph accelerometer during 4-hour lessons of different types of education days. The result is that outdoor education can serve as an appropriate complement to learning that contributes to the development of pupils' knowledge and skills while working in a real environment but also acts as a mean of increasing the possibilities for movement for pupils during their schooling.
\end{abstract}

Keywords: outdoor education; elementary school; physical activity assessment; health promotion; accelerometry

\section{INTRODUCTION}

Movement (physical activity) is an integral part of human life and, at the same time, one of the important needs of each child (pupil/student). Neumann (2000, p. 24) states that "we live at a time when the physical fitness of the population is on the downgrade and movement activity is often replaced by passive ways of entertainment" (e.g., playing on the PC, watching TV, etc.). An international study Health Behaviour in School-Aged Children compared the movement activities of schoolchildren ages 11, 13, and 15 of 48 countries in Europe and North America including Central Europe (Czechia, Slovakia, Poland, Hungary, and Ukraine) also shows that more and more European students are lacking in physical activity (Madarasová Gecková et al., 2016). Similarly, there is evidence of the increased prevalence of childhood obesity in the UK (Lobstein, James, \& Cole, 2003) or the USA (Lobstein \& Jackson-Leach, 2007; Lee, Stodden, \& Gao, 2016). Since a hypo-kinetic lifestyle prevails among children today (as well as among adult population), teachers could do more to promote the healthy development of pupils supported by movement activity (Mužík \& Krejčí, 1997). The movement inadequacy, or hypokinesia, occurs in children and adults and its manifestations are not only physical but also psychological (Krejčí, 2011). As the current lifestyle of many children and adults is not good, a positive attitude towards movement and a healthy lifestyle should be built up already in school-aged children.

Mužík and Krejčí (1997) recommend 30 minutes of a lower intensity movement activity (light to moderate) a day, to which 30 minutes of medium intensity movement (moderate to vigorous) should be added at least three times a week. As compared to Mužík and Krejčí, the demands of Sigmund and Sigmundová (2011) for the daily movement activity of early school-age children are significantly higher. In their opinion, the medium intensity daily movement activity of children should be three times longer, i.e., 90 minutes. Strong et al. (2005) recommend at least 60 minutes per day of moderate to vigorous intensity of physical activity. 
There are several strategies on how to raise the intensity of physical activity. Steele et al. (2010) speak about promoting physical activity during weekdays after school and weekends. We focus on increasing physical activity during school-time, because this time can take up more than $1 / 3$ of the pupil's total daily time without the required time for sleeping. Wareham, van Sluijs and Ekelund (2005) claim that when examining the most effective school-based interventions, it appears that such interventions are indeed limited to structured activity through predominantly physical education classes. However, movement can be largely incorporated into the teaching of most subjects at elementary school. If we disregard the actual physical education, which is a compulsory subject, then the movement can be incorporated mainly by means of outdoor education, which is an integral part of the natural sciences (geography, biology). It can also be applied to most social science subjects. Outdoor education is inherently associated with movement activities. Still, the movement itself is not a necessary priority for such form of education and that pupils sometimes may not even realize its importance. In the outdoors, pupils move on foot to various places during the collection of primary data for later processing. We see one of the most significant values of outdoor education in the fact that it combines elements of physical education with the transfer of subject-oriented schoolwork in natural science subjects and the humanities to the pupils.

The compatibility of physical education and outdoor education has already been described in Bunting (1989), who compared physical education and outdoor education objectives. Both physical and outdoor education directly or indirectly develop skills, social domains, physical fitness, and the process of learning. Moreover, outdoor education emphasizes environmental interdependency (Martin \& McCullagh, 2011). In some countries, the outdoor education is considered to be so important that it has its own curriculum (Australia - Gray \& Martin, 2012; New Zealand - Boyes, 2000; Denmark - Bentsen, Mygind, \& Randrup, 2009).

In Czechia, the benefits of outdoor education have been described in general based on the view of teachers (Svobodová, Mísařová, \& Hofmann, 2016), while in foreign literature the numerous benefits of outdoor education have been deeply analysed in various studies (Meredith, Fortner, \& Mullins, 1997; Neill \& Richards, 1998; Knapp, 2000; Rickinson et al., 2004; Fuller, Edmondson, France, Higgitt, \& Ratinen, 2006; Shin, 2007; Mygind, 2007, 2009; Park, Tsunetsugu, Kasetani, Kagawa, \& Miyazaki, 2010; Cooper et al., 2010; Karppinen, 2012). The specific benefit of outdoor education on the development of natural movement activity has been investigated only partially in the context of Czech schooling (Korvas, 2005; Hofmann \& Korvas, 2008). These researches, however, consisted of a measurement of the number of steps in different activities which are typical for integrated outdoor education. Later, the step count and MET rate has been gauged by Trávníček, Svobodová, and Durna (2018) on school aged children during different types of learning lessons.

However, outdoor education is also connected with the need to overcome a wide range of organizational, safety, as well as methodological obstacles (Waite 2009; Yang, Wang, Xu, \& Deng, 2014). Therefore, it is not surprising that it remains the domain of only the most daring educators in the Czechia (Smrtová, Zadabal, \& Kovaříková, 2012). It is necessary to add that the study courses for outdoor educators, as are usual in more developed countries (Thorburn \& Allison, 2010; Lugg \& Martin, 2001), are missing in Czechia.

The facts described above bring us to the aims of this paper. The influence of outdoor education on the Czech pupils' knowledge and skills were described in another authors' paper (Svododová, Mísařová, Durna, \& Hofmann, 2019). The influence of outdoor education on the pupils' movement activity needs to be more investigated (among Czech pupils) as compared to learning in a classroom. The absence of repeated sophisticated measurement of pupils' movement activity and its comparison in different educational units implies the aim of this paper. The aim 
of our study is to find out how can outdoor education contribute to the physical activeness of the pupils during school-time. Our research question is following: Is the pupil's physical activity during the day of outdoor education comparable or lower/higher to their physical activity during sedentary classroom education with/without the PE lesson?

To reach this aim, we compared the data gained from the physical activity measurement during the following forms of education: 1) all day classroom education, 2) classroom education with the incorporation of a physical education lesson, 3) outdoor education.

\section{ANCHORING MOVEMENT AND OUTDOOR EDUCATION IN THE CZECH CURRICULUM}

The educational objectives and content of the Czech curricula are defined in the Framework Education Programs (FEPs), which represent the national level of educational content. These centrally drafted curricular programs are binding for all elementary and secondary schools. The FEPs provide a foundation for the School Education Programs (SEPs) that are set at the school level to help teachers refine and customize the objectives and content of the subjects they teach (Vlček et al., 2016).

The FEPs specify (1) the level of key competencies that pupils should acquire by the end of specific education grade, (2) define an obligatory content of education (expected outcomes and curriculum), and (3) integrates cross-curricular topics as an obligatory part of education.

The educational content is divided into nine educational areas. Movement activities can be explicitly found only in the part of FEP called Man and Health educational area (incorporated in all nine grades of Czech elementary schools and it includes both Physical Education and Health Education - the given minimum of two hours per week in all grades).

In other educational areas, movement can be incorporated, for example, in the following ways, whereupon Jacobs (1989) speaks about complementary units in this context:

(1)A minute for health - pupils should break up long periods of sitting down with a minute of physical activity, during which they perform some movement exercises.

(2)Class lessons - teachers can prepare simple physical/sports activities in the course of regular lessons in the classroom (traditional dances in geography or music lesson).

(3)Outdoor education. As outdoor education is the key term for our paper, we add our own definition according to Hofmann (2003) and later adjusted by Svobodová, Mísařová and Hofmann (2016).

"Outdoor education is an 'umbrella' concept for multiple forms of education, with the common feature of being undertaken outdoors, outside of school buildings. Outdoor education can take on a variety of organizational forms, from didactic walks, excursions, and field exercises to field research. If an outdoor education should have any benefits for students, they must be actively performing activities such as collecting and processing information from primary and secondary sources, using the research methods and aids of individual scientific disciplines".

The definition of OEA (2010, n. p.) adds that "outdoor education provides unique opportunities to develop a positive relationship with the environment (or experiential knowledge as is said in VCAA, 2005, p. 7), others and ourselves through interaction with the natural world." 
One of the priorities of the Framework Educational Program is the consistent use of intersubject links and the integration of the educational content of various subjects. Outdoor education, which can be an integral part of many subjects (especially the natural sciences), is an appropriate form of teaching to meet these inter-subject links, leading to the cooperation of teachers in various educational areas. From the above- mentioned possibilities for incorporating movement into learning, outdoor education can be considered in terms of its benefits on the development of movement activity and the development of key competencies as the most complex form of education.

In relation to outdoor education, it is only up to the teachers themselves how they will transfer all of the activities into the School Educational Program and subsequently to educational units. There are sufficient prerequisites for the application of outdoor education in the Czech curriculum, but its realization in practice often fails (Svobodová, Mísařová, \& Hofmann, 2016). It is mainly because the benefits of outdoor education not only for physical activity are not yet widely appreciated among Czech teachers as no institution provides them appropriate education in the field of outdoor education.

From the point of view of didactics, outdoor education in the Czech education system is often included on the basis of the "traditional" concept of teaching. The methods of its implementation at many Czech schools nowadays are considered as ways that have already been overcome abroad. This means that outdoor education is rather associated with excursions, school trips, and other activities where pupils are merely observers and passive recipients of information - not active researchers, as exemplified in Oost, De Vries and van der Schee (2011). The different forms of outdoor education units contribute differently to the development of natural movement activity.

\section{METHODS}

\section{Participants}

Measurements of physical activity were taken in May 2017 for pupils of the $5^{\text {th }}$ grade (age 9-11, i.e., $\mathrm{K}-5$ ) and $8^{\text {th }}$ grade (age 13-14, i.e., $\mathrm{K}-8$ ) of the elementary school, where all day long outdoor education is used regularly in each of those grades $\left(5^{\text {th }}\right.$ and $\left.8^{\text {th }}\right)$. So, this was the main reason why we conducted research on pupils in described age groups. We also wanted to avoid the research distortion where possible. Therefore, all lessons were conducted under the guidance of the teacher, to whom the pupils were accustomed. The present researcher only assured the correct setting and deployment of physical activity sensors. The sample for pupil measurement was limited by the number of ActiGraph monitoring devices to 10 pupils per grade that mean 20 pupils in total (ten for $5^{\text {th }}$ grade and ten for the $8^{\text {th }}$ grade). These ten devices were distributed among pupils using a stratified selection. In the $5^{\text {th }}$ grade group, boys and girls were equally represented (five male and five female pupils). In the $8^{\text {th }}$ grade group, there was only one male pupil, and the rest of the group represent nine female pupils. The reason for this sex disproportion was caused by the deficiency of boys in $8^{\text {th }}$ grade (and the actual health condition of the other male pupil prevent him from participation in the research). So the sex ratio $(F: M)$ of the sample $(n=20)$ was 2.3 : 1. More detailed information about each participant (BMI, BMI percentile, age) is shown in Table 1. Due to sample size we consider this research as the pilot study. Nevertheless, we believe that the data and methods presented here can be used by other fellow researchers, who are interested in research of children's physical activity during their schooling. 
Table 1. BMI percentile and weight status of $5^{\text {th }}$ and $8^{\text {th }}$ grade probands according to the $6^{\text {th }}$ NAS methodology.

\begin{tabular}{rccclclcccll}
\hline \multicolumn{1}{c}{$5^{\text {th }}$ grade } & \multicolumn{9}{c}{$8^{\text {th }}$ grade } \\
P5 & AGE & SEX & BMI & BMI P & WS & P8 & AGE & SEX & BMI & BMI P & WS \\
\hline 1 & 9 & M & 14,7 & $10-25$ & slim & 1 & 13 & F & 18,0 & $25-50$ & prop. \\
2 & 10 & M & 15,8 & 25 & prop. & 2 & 13 & F & 18,8 & $25-50$ & prop. \\
3 & 9 & M & 16,4 & 50 & prop. & 3 & 13 & F & 17,3 & $25-50$ & prop. \\
4 & 9 & M & 15,2 & 25 & prop. & 4 & 13 & F & 16,5 & $10-25$ & slim \\
5 & 9 & M & 21,3 & 97 & overweight & 5 & 13 & F & 20,8 & 75 & at risk \\
6 & 10 & F & 16,9 & $25-50$ & prop. & 6 & 14 & F & 19,5 & 50 & prop. \\
7 & 9 & F & 21,4 & $97-99$ & obese & 7 & 14 & M & 24,1 & $90-97$ & overweight \\
8 & 10 & F & 16,6 & $25-50$ & prop. & 8 & 14 & F & 19,5 & 50 & prop. \\
9 & 9 & F & 18,1 & 75 & prop. / at risk & 9 & 13 & F & 22,6 & 90 & at risk \\
10 & 11 & F & 19,5 & $75-90$ & at risk & 10 & 13 & F & 18,4 & $25-50$ & prop. \\
\hline
\end{tabular}

Legend: P5, P8 - proband of $5^{\text {th }}$ and $8^{\text {th }}$ grade; BMI P - BMI percentile (specific to the age of probands); WS - weight status (according to the $6^{\text {th }}$ NAS); prop. - proportional. Probands are labelled by the number of worn ActiGraph device (first column of the table). Column BMI percentile (BMI P) contain information if BMI value of proband lies directly on the edge of interval (single number) or if the value lies in the interval of value range.

\section{Instrumentation}

The physical load of the pupils was monitored by the ActiGraph wGT3X-BT accelerometers. Twenty participants were instructed to wear the monitoring device on the right hip during the education units. Activity data were recorded at 10 -second intervals. Data processing and evaluation were done with hourly averages of the measured data. Every measured education unit lasted 4 hours.

We focused on the values of the energy consumed in kcal and the metabolic output in MET (metabolic equivalent of task). One MET is defined as the resting metabolic rate, represented by the amount of oxygen consumed at rest (sitting quietly), approximately $3.5 \mathrm{ml} \mathrm{O} / \mathrm{kg} / \mathrm{min}$ (or $1.2 \mathrm{kcal} / \mathrm{min}$ for a $70-\mathrm{kg}$ person; Jetté, Sidney, \& Blümchen, 1990). For example, the energy cost of playing rugby is 8.3 METS, which means the use 8.3 times more energy than sitting quietly and rest (M.E.T.S., 2016).

For each pupil, the value of kcals was recorded for the same time interval that is for four hours over three days, with a different form of learning represented on each day. For regular lessons lasting 45 minutes, the break time $(3 \times 10$ and $1 \times 20$ minutes $)$ is also included.

The ActiGraph accelerometer is also able to process the sedentary analysis. We focused on the total length of sedentary bouts, i.e., the total sedentary time in minutes detected during four hours of different types of learning. So, we can also compare the time spent (by the probands) on sitting for each educational unit.

\section{Procedure}

Given that we are aware of certain research limitations, which include the different levels of movement activity during different learning units and different types of outdoor education, we have carried out first measurements with $5^{\text {th }}$ grade pupils and later a control measurements with pupils of the $8^{\text {th }}$ grade at the same school. The conditions were similar for both grades - pupils completed four hours of classroom lessons without PE, four hours of indoor lessons including two lessons of PE (i.e., 2 times as much as the grade 5), and four hours of outdoor education. 
The representation of girls (9) and boys (1) in the evaluated sample was uneven, as there were only 2 boys in the class.

\section{Data Analysis}

Before the physical activity measurement, the height and weight of probands were recorded, and the body mass index (BMI) was calculated for each of them. We are aware that simple value of BMI is not very useful for assessment of weight status of children and youth, so we adapted the method of BMI percentile which is more suitable for children and adolescents due to fluctuations in height, weight, and body composition that occur in the growth stages. BMI percentile tends to be a more sensitive tool to the change in the weight status of growing children and adolescents (Hoelscher, Kirk, Ritchie, \& Cunningham-Sabo, 2013; Price, Cohen, Pribis, \& Cerami, 2017).

For Czech children, weight status is determined using BMI age and sex norm-referenced values derived from the national wide survey. In Table 1 there is the BMI percentile and the weight status of all probands. Using the $6^{\text {th }}$ National wide Anthropological Survey (Kobzová, Vignerová, Bláha, Krejčovský, \& Riedlová, $2006-6^{\text {th }}$ NAS) growth charts, obesity is defined as a BMI $\geq 97^{\text {th }}$ percentile and overweight is $\mathrm{BMI} \geq 90^{\text {th }}$ and $<97^{\text {th }}$ percentile and the zone at risk of overweight is defined as a BMI $>75^{\text {th }}$ and $<90^{\text {th }}$ percentile. The proportional zone (regular weight in specific age) lies between the $\geq 25^{\text {th }}$ and $\leq 75^{\text {th }}$ percentile, and slim is defined as a $<25^{\text {th }}$ percentile. Values below the $3^{\text {rd }}$ percentile indicate the very severe underweight. Authors are aware that BMI percentile limit values may differ among the other authors, so we use these values only in the Czech anthropo-socio-cultural context. We use the above-described method to inform about the weight status (WS) of probands (see Table 1).

To interpret the measured data, we used three kinds of analysis provided by the ActiLife (actigraphy data analysis software platform). Firstly, the Energy Expenditure (analysis of the calories burned) of each proband during three different types of learning was carried out. Secondly, we considered the MET rates values reached by the probands. Finally, the Sedentary Bouts (analysis of low activity describing the proband's sedentary behavior) were calculated in the ActiLife software.

To interpret the data coming from the analysis described above, we adopted the methods of descriptive statistic (average value) and data significance level. We combined all the data described above in an attempt to discuss one of the potential benefits of outdoor education - the increased physical activity during this type of education.

\section{RESULTS}

\section{Energy Expenditure}

The results of ActiGraph measuring of the calories burned by the $5^{\text {th }}$ grade pupils (Table 2 ) show that the average energy expenditure among the probands was $23.8 \mathrm{kcal}$ per a regular learning day without PE (exactly four hours of learning). On a learning day wherein PE is incorporated, the average energy expenditure was $57.2 \mathrm{kcal}$. For outdoor education day, the average energy expenditure was $189.3 \mathrm{kcal}$, i.e., three times more than on a learning day with PE and eight times more than on the learning day without PE. This result suggest that outdoor education may contribute significantly to the daily energy expenditure.

The results of $8^{\text {th }}$ grade pupils' movement activity (Table 2) show a higher energy expenditure than in the group of the $5^{\text {th }}$ grade pupils in all cases. Differences between classes can be explained, in particular, due to different pupil activities during the individual types of learning as well as the different individual biometric characteristics of pupils in grades 5 and 8 . 
On a regular learning day without $\mathrm{PE}$, the average energy consumed value was $53.4 \mathrm{kcal}$. For a learning day where PE was incorporated, the average energy consumed value was $110.6 \mathrm{kcal}$. During outdoor education of the same time range as learning at school, the average energy consumed value was $277.7 \mathrm{kcal}$, i.e., 2.5 times more than during the learning day with PE and five times more than during the school day without PE.

Table 2. Energy expenditure ( $\mathrm{kcal}$ ) of the $5^{\text {th }} \& 8^{\text {th }}$ grade pupils during 4 hours of different types of education

\begin{tabular}{|c|c|c|c|c|}
\hline \multicolumn{5}{|l|}{$5^{\text {th }}$ grade pupils } \\
\hline Pupil (sex) & $\begin{array}{l}\text { Weight status } \\
\text { (see table } 1)\end{array}$ & $\begin{array}{c}\text { Classroom educa- } \\
\text { tion without PE }\end{array}$ & $\begin{array}{c}\text { Classroom educa- } \\
\text { tion with PE }\end{array}$ & $\begin{array}{r}\text { Outdoor } \\
\text { education }\end{array}$ \\
\hline pupil $1(\mathrm{M})$ & slim & 27,117 & 41,711 & 157,456 \\
\hline pupil $2(\mathrm{M})$ & proportional & 22,965 & 84,447 & 266,275 \\
\hline pupil $3(\mathrm{M})$ & proportional & 21,045 & 32,856 & 136,660 \\
\hline pupil $4(\mathrm{M})^{\star}$ & proportional & 11,286 & 23,270 & 41,431 \\
\hline pupil $5(\mathrm{M})$ & overweight & 33,074 & 70,778 & 235,441 \\
\hline pupil $6(\mathrm{~F})$ & proportional & 18,550 & 40,640 & 151,332 \\
\hline pupil 7 (F) & obese & 11,100 & 74,025 & 199,620 \\
\hline pupil $8(\mathrm{~F})$ & proportional & 41,116 & 82,842 & 199,511 \\
\hline pupil $9(\mathrm{~F})$ & prop./ at risk & 20,676 & 38,221 & 134,540 \\
\hline pupil $10(\mathrm{~F})$ & at risk & 31,127 & 83,475 & 371,074 \\
\hline Average - male & - & 23,097 & 50,612 & 167,453 \\
\hline Average - female & - & 24,514 & 63,841 & 211,215 \\
\hline Average & - & 23,806 & 57,227 & 189,334 \\
\hline \multicolumn{5}{|l|}{$8^{\text {th }}$ grade pupils } \\
\hline Pupil (sex) & $\begin{array}{l}\text { Weight status } \\
\text { (see table } 1)\end{array}$ & $\begin{array}{c}\text { Classroom educa- } \\
\text { tion without PE }\end{array}$ & $\begin{array}{c}\text { Classroom educa- } \\
\text { tion with PE }\end{array}$ & $\begin{array}{r}\text { Outdoor } \\
\text { education }\end{array}$ \\
\hline pupil $1(\mathrm{~F})$ & proportional & 47,940 & 130,320 & 403,870 \\
\hline pupil $2(\mathrm{~F})$ & proportional & 70,971 & 71,878 & 241,360 \\
\hline pupil $3(\mathrm{~F})$ & proportional & 30,303 & 49,188 & 205,811 \\
\hline pupil $4(\mathrm{~F})$ & slim & 38,882 & 95,946 & 191,747 \\
\hline pupil $5(\mathrm{~F})$ & at risk & 54,337 & 176,880 & 302,487 \\
\hline pupil $6(\mathrm{~F})$ & proportional & 44,347 & 61,424 & 291,894 \\
\hline pupil 7 (M) & overweight & 77,686 & 205,830 & 362,866 \\
\hline pupil $8(\mathrm{~F})$ & proportional & 53,025 & 95,306 & 233,740 \\
\hline pupil $9(\mathrm{~F})$ & at risk & 57,785 & 89,396 & 319,096 \\
\hline pupil $10(\mathrm{~F})$ & proportional & 58,389 & 129,710 & 223,820 \\
\hline Average - male & - & 77,686 & 205,830 & 362,866 \\
\hline Average - female & - & 50,664 & 100,005 & 268,203 \\
\hline Average & - & 53,367 & 110,588 & 277,669 \\
\hline
\end{tabular}

Source: own ActiGraph measurements, own calculations

* The lower measured values for pupil 4 can be explained by the partially incorrect measurement of the ActiGraph - see the limitations of the research for further detail.

\section{Metabolic Equivalent of Task}

The value of the Metabolic equivalent of task (MET) per individual per time provides information about how intensive is the executed physical activity of proband compared to sitting still (MET = 
1). We compared the average MET rate achieved during the three types of learning (Table 3) and all values strongly differ from 1 (basal metabolic rate). This is interesting, especially in case of learning in the classroom, but it can be probably explained by the fact that pupils do not sit still during the lessons all the time (they move on the chair, sometimes walk around the room, they move during the breaks, etc.). MET rates achieved during learning in the classroom including the PE lesson was in the case of $5^{\text {th }}$ grade 1.3 times higher (on average) compared to classroom learning without PE and similarly 1.2 times higher in the case of $8^{\text {th }}$ grade (similarly the Energy Expenditure was higher in all cases). If we compare the MET rate achieved by probands during the outdoor education to MET rate achieved in the classroom, the outdoor shows the 2.6 times higher values (on average) in case of $5^{\text {th }}$ grade and 1.9 times higher values in case of $8^{\text {th }}$ grade pupils. The ratio of the difference of MET rate and energy expenditure among the $5^{\text {th }}$ and $8^{\text {th }}$ grades is the same (close to the value $1.4 \times$ ).

Table 3. MET rates of the $5^{\text {th }} \& 8^{\text {th }}$ grade pupils during 4 hours of different types of education

\begin{tabular}{|c|c|c|c|c|}
\hline \multicolumn{5}{|l|}{$5^{\text {th }}$ grade pupils } \\
\hline Pupil (sex) & $\begin{array}{l}\text { Weight status } \\
\text { (see table } 1)\end{array}$ & $\begin{array}{l}\text { Classroom educa- } \\
\text { tion without } \mathrm{PE}\end{array}$ & $\begin{array}{c}\text { Classroom educa- } \\
\text { tion with PE }\end{array}$ & Outdoor education \\
\hline pupil $1(\mathrm{M})$ & slim & 1,55 & 1,89 & 4,06 \\
\hline pupil $2(\mathrm{M})$ & proportional & 1,38 & 1,98 & 3,97 \\
\hline pupil $3(\mathrm{M})$ & proportional & 1,42 & 1,70 & 3,64 \\
\hline pupil $4(\mathrm{M})^{\star}$ & proportional & 1,28 & 1,52 & 3,52 \\
\hline pupil $5(\mathrm{M})$ & overweight & 1,41 & 1,72 & 3,30 \\
\hline pupil $6(\mathrm{~F})$ & proportional & 1,29 & 1,52 & 3,30 \\
\hline pupil 7 (F) & obese & 1,15 & 1,75 & 3,52 \\
\hline pupil $8(\mathrm{~F})$ & proportional & 1,57 & 1,91 & 3,37 \\
\hline pupil $9(\mathrm{~F})$ & prop./ at risk & 1,37 & 1,75 & 3,75 \\
\hline pupil $10(\mathrm{~F})$ & at risk & 1,32 & 1,66 & 3,74 \\
\hline Average - male & - & 1,41 & 1,76 & 3,70 \\
\hline Average - female & - & 1,34 & 1,72 & 3,54 \\
\hline Average & - & 1,37 & 1,74 & 3,62 \\
\hline
\end{tabular}

\begin{tabular}{llccc}
\hline $\mathbf{8}^{\text {th }}$ grade pupils & Weight status & $\begin{array}{c}\text { Classroom educa- } \\
\text { tion without PE }\end{array}$ & $\begin{array}{c}\text { Classroom educa- } \\
\text { tion with PE }\end{array}$ & Outdoor education \\
Pupil (sex) & (see table 1) & 1,28 & 1,74 & 3,07 \\
\hline pupil 1 (F) & proportional & 1,59 & 1,59 & 2,63 \\
pupil 2 (F) & proportional & 1,28 & 1,43 & 2,53 \\
pupil 3 (F) & proportional & 1,34 & 1,81 & 2,52 \\
pupil 4 (F) & slim & 1,32 & 1,97 & 2,57 \\
pupil 5 (F) & at risk & 1,27 & 1,38 & 2,54 \\
pupil 6 (F) & proportional & 1,42 & 1,93 & 2,40 \\
pupil 7 (M) & overweight & 1,44 & 1,72 & 2,57 \\
pupil 8 (F) & proportional & 1,33 & 1,75 & 2,59 \\
pupil 9 (F) & at risk & 1,48 & 1,69 & 2,75 \\
pupil 10 (F) & proportional & 1,42 & 1,93 & 2,40 \\
Average - male & - & 1,37 & 1,67 & 2,64 \\
Average - female & - & 1,40 & 1,80 & 2,52 \\
Average & - & & & \\
\hline
\end{tabular}

Source: own ActiGraph measurements, own calculations 


\section{Sedentary Analysis}

The learning day without the PE lesson(s) or outdoor education was mainly (more than $80 \%$ of the time spent by pupils) in a sedentary way - see Figures 1 and 2. Pupils spended about $20 \%$ of the time in light or moderate movement, which roughly corresponds to the period of time of a break when pupils can move freely (a total of 40 minutes of the 240 minutes measured). During a learning day with the inclusion of $\mathrm{PE}$, there was a higher proportion of time when pupils engage in moderate movement - approx. 15-20\%. The representation of light movement was similar to a day without PE, i.e., approx. $10 \%$. As opposed to a learning day without $\mathrm{PE}$, the vigorous movement type prevails here at a higher rate (approx. 3-5\%).

The different representation of movement activity was also apparent in different outdoor education days. Although the sedentary type prevailed in $8^{\text {th }}$ grade group (because there was a task insisting a lot of writing), it was not the same case in the $5^{\text {th }}$ grade group where the moderate movement type prevailed. Nevertheless, the vigorous movement type was represented by about $15 \%$ in both assessed groups.

\section{Sedentary analysis of three types of education (Grade 5)}

Education without PE

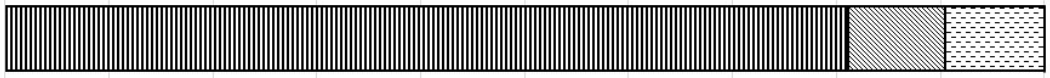

Education with PE

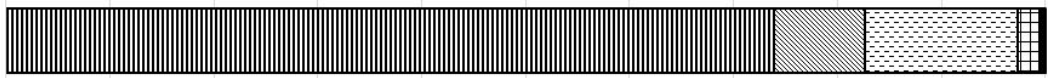

Outdoor education

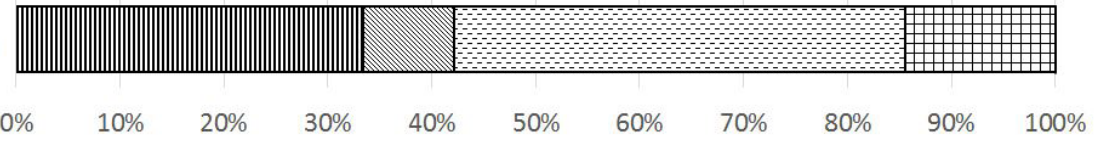

m Sedentary $\mathbb{\Delta}$ Light $\mathbf{0}$ Moderate $\mathbf{\square}$ Vigorous $\mathbf{Q}$ Very Vigorous

Figure 1: Sedentary analysis results ( $5^{\text {th }}$ grade pupils).

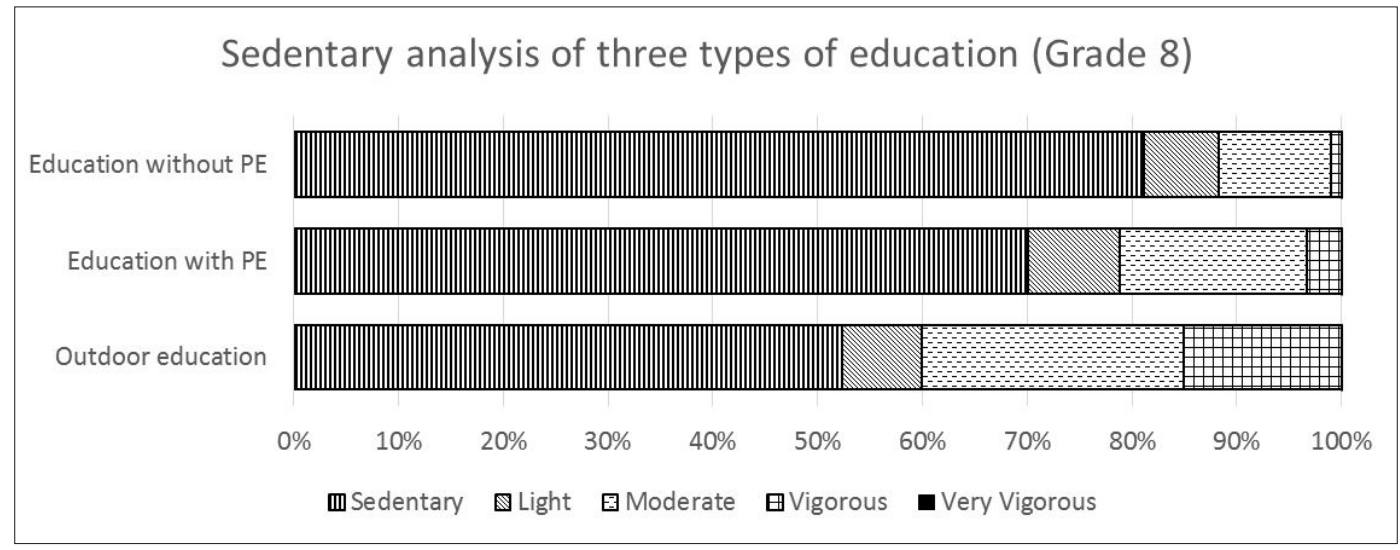

Figure 2: Sedentary analysis results ( $8^{\text {th }}$ grade pupils).

Overall, the benefit of outdoor education, both in terms of the contribution to the daily calorie consumption and in terms of sedentary analysis, can be more positively evaluated than "common" education. If we compared 1 hour of outdoor education and 1 hour of PE, then the 
$8^{\text {th }}$ grade pupils consumed an average of $48.2 \mathrm{kcal}$ during one hour of PE and $107.3 \mathrm{kcal}$ during one hour of outdoor education, while $5^{\text {th }}$ grade pupils consumed $30.8 \mathrm{kcal}$ during one hour of $\mathrm{PE}$ and $39.1 \mathrm{kcal}$ during one hour of outdoor education. From these data, it can be concluded that in specific cases even an hour of outdoor education may have a slightly larger benefit on pupils' movement activity than an hour of PE. This can be caused by specific conditions during particular lessons. In both cases of outdoor education, pupils had to be active (physically) during the whole session of the measured period because they have to walk, observe, measure etc., all the time. Although during the PE lesson in the $8^{\text {th }}$ grade pupils played volleyball (and ran at the beginning of lesson to warm-up the body), there were some blind spots where the physical activity was lower (e.g., when some active child was performing an excellent play, while the less active one was nearly standing still and waiting). Of course, this can vary depending on given sport and children attitude to sports activity.

\section{DISCUSSION}

Before we approach to the discussion of possible implication for the school practice, we would like to describe the limitations of this pilot study that we found out during the research. We believe it is correct to do so before formulation of the finishing statements as it can help to replicate the research without these obstacles.

\section{Limitations}

The authors of the paper are aware of several limitations of the presented research. Data collection was limited by the technological burden of the used device. The chest strap with the heart rate detector is primarily designed for an adult body. For children, the length of the chest strap had to be adjusted. Although we try to fix the strap on the children's chest, sometimes the detector was not recording the data for all of the 10-seconds intervals (in cases of very slim body type). The percentage of the measured data averages over $75 \%$ for all pupils; the data significance level $\mathrm{p}$ has been calculated for the measured data sets, which is in all cases $\mathrm{p}>0.20$, meaning that the differences between the measured data are not significant and can be used for further analysis. Another limitation is the quite small sample, so we cannot allow generalizing the results on the population. Though the limitations of the obtained results, but we believe this can be a valuable tool for the larger-scale measurements and deeper statistical analysis of physical activity achieved during school activities of Czech pupils.

\section{Implications for School Practice}

At a time when the physical fitness of youth is decreasing (Madarasová Gecková et al., 2016; Lobstein, James, \& Cole, 2003; Lobstein \& Jackson-Leach, 2007; Lee, Stodden, \& Gao, 2016) already from an early age compared to previous years, the schools should seek different ways to contribute to the development of pupils in this field. One of the ways how elementary schools can contribute to the development of movement activity to a certain extent is through the more frequent incorporation of outdoor education, both in short-term (1-2 learning hours) and medium-term forms (usually one day), as well as long-term forms (two and more days outside the school building). During well thought-out outdoor learning sessions, pupils are given a chance to be engaged in natural unstructured movement (walking, running, cycling) and, at the same time, to develop their knowledge and skills while not missing out on their schoolwork.

The results of pilot study suggest that the movement activity performed by pupils during outdoor education could be comparable to the activity that pupils perform during some physical 
education lessons. Nonetheless, there are limited hours for PE during a school week. However, outdoor education can be cross-sectionally incorporated into almost all subjects and, inter alia, develop inter-subject links - naturally between physical education and other subjects. It is also an advantage not only for the natural sciences that pupils learn in a real environment, which corresponds to current trends in education (Vlček et al., 2016; Adkins \& Simmons, 2002).

However, the principles of incorporating outdoor education into school education are not elaborated in great detail in the Czech education system. Many teachers still incorporate outdoor education in poorly designed ways (e.g. without links to the schoolwork discussed in class, with little pupil's own activity). Therefore, further research steps consist of: 1) the extension of the sample of measured pupils in different types of learning to make results of measurements more relevant, and 2) the preparation of the methodology of outdoor education, including the deepening of inter-subject cooperation. The teachers could be helpful partners in both - the cooperation in measurement of physical activity and preparation of school conception with clearly defined objectives how to strengthen the role of outdoor education at their school.

\section{CONCLUSION}

In the approach to the measurements, the researchers have been inspired in particular by researchers (Steele et al., 2009) who used the ActiGraph device for investigations of patterns of children sedentary and vigorous physical activity throughout the week. In another research (Fairclough, Beighle, Erwin, \& Ridgers, 2012) authors measured the patterns of physical activity of differently active pupils during a school-day.

The results of the research on the movement activity of school-age pupils suggest that the outdoor education can contribute to its increasing (just simple walking during the outdoor education seems to be a great booster of MET rate and daily energy expenditure). Based on the results, it can be concluded that outdoor education can contribute to the development of the natural movement activity of pupils. It seems to be valuable to look deeper on the outdoor education from the point of the physical activity and thus it can be interesting for school authorities.

\section{FUNDING:}

This work was supported by the Czech Science Foundation under Grant 16-00695S "Fieldwork as a powerful learning strategy".

\section{References}

Adkins, C., \& Simmons, B. (2002). Outdoor, Experiential, and Environmental Education: Converging or Diverging Approaches? Charleston, WV: ERIC Digest.

Bentsen, P., Mygind, E., \& Randrup, T. B. (2009). Towards an understanding of udeskole: education outside the classroom in a Danish context. Education 3-13, 37(1), 29-44. doi: https://doi.org/10.1080/03004270802291780.

Boyes, M. (2000). The place of outdoor education in the health and physical education curriculum. New Zealand Physical Educator, 33(2), 75-88.

Bunting, C. J. (1989). The compatibility of physical education and outdoor education. Journal of Physical Education, Recreation \& Dance, 60(2), 35-39.

Cooper, A. R., Page, A. S., Wheeler, B. W., Hillsdon, M., Griew, P., \& Jago, R. (2010). Patterns of GPS measured time outdoors after school and objective physical activity in English children: The PEACH project. International Journal of Behavioral Nutrition and Physical Activity, 7(31), 1-9. doi: https://doi.org/10.1186/1479-5868-7-31.

Fairclough, S. J., Beighle, A., Erwin, H., \& Ridgers, N. D. (2012). School day segmented physical activity patterns of high and low active children. BMC public health, 12(406), 1-12. 
Fuller, I. A. N., Edmondson, S., France, D., Higgitt, D., \& Ratinen, I. (2006). International perspectives on the effectiveness of geography fieldwork for learning. Journal of Geography in Higher Education, 30(1), 89-101. doi: https://doi. org/10.1080/03098260500499667.

Gray, T., \& Martin, P. (2012). The role and place of outdoor education in the Australian National Curriculum. Journal of Outdoor and Environmental Education, 16(1), 39-50. doi: https://doi.org/10.1007/BF03400937.

Hoelscher, D. M., Kirk, S., Ritchie, L., \& Cunningham-Sabo, L. (2013). Position of the Academy of Nutrition and Dietetics: Interventions for the Prevention and Treatment of Pediatric Overweight and Obesity. Journal of the Academy of Nutrition and Dietetics, 113(10), 1375-1394. doi: https://doi.org/10.1016/j.jand.2013.08.004.

Hofmann, E. (2003). Integrované terénní vyučování. Brno: Paido.

Hofmann, E., \& Korvas, P. (2008). Terénní výuka s pohybovými aktivitami. Geographia cassovensis, 2(1), 47-52.

Jacobs, H. H. (1989). Interdisciplinary curriculum: Design and implementation. Alexandria: Association for Supervision and Curriculum Development.

Jetté, M., Sidney, K., \& Blümchen, G. (1990). Metabolic equivalents (METS) in exercise testing, exercise prescription, and evaluation of functional capacity. Clinical 13(8): 555-565.

Karppinen, S. (2012). Outdoor adventure education in a formal education curriculum in Finland: Action research application. Journal of Adventure Education and Outdoor Learning, 12(1), 41-62. doi: http://doi.org/10.1080/14729679.2011.569186.

Knapp, D. (2000). Memorable experiences of a science field trip. School science and mathematics, 100(2), 65-72. doi: http:// doi.org/10.1111/j.1949-8594.2000.tb17238.x.

Kobzová, J., Vignerová, J., Bláha, P., Krejčovský, L., \& Riedlová, J. (2006). 6th Nation-wide Anthropological Survey of Children and Adolescents 2001. Czech Republic. Praha: PřF UK v Praze.

Korvas, P. (2005). Intensity load and energy cost at the geographical terrain practice with sports activities. Acta Universitatis Matthiae Belii, Physical Education and sport, 6(6), 59-64.

Krejčí, M. (2011). Výchova ke zdraví a strategie výuky duševní hygieny ve škole. České Budějovice: Jihočeská univerzita.

Lee, J. E., Stodden, D. F., \& Gao, Z. (2016). Young children's energy expenditure and moderate-to-vigorous physical activity on weekdays and weekends. Journal of Physical Activity and Health, 13(9), 1013-1016. doi: https://doi.org/10.1123/ jpah.2015-0725.

Lobstein, T. J., James, W. P. T., \& Cole, T. J. (2003). Increasing levels of excess weight among children in England. International journal of obesity, 27(9), 1136-1138.

Lobstein, T., \& Jackson-Leach, R. (2007). Child overweight and obesity in the USA: prevalence rates according to IOTF definitions. Pediatric Obesity, 2(1), 62-64.

Lugg, A., \& Martin, P. (2001). The nature and scope of outdoor education in Victorian schools. Journal of Outdoor and Environmental Education, 5(2), 42-48.

M.E.T.S. (2016). BrainMAC Sports Coach [online]. URL https://www.brianmac.co.uk/mets.htm.

Madarasová Gecková, A. (Ed.) (2016). Mezinárodní zpráva o zdraví a životním stylu dětí a školáků na základě výzkumu studie Health Behaviour in School-Aged Children realizované v roce 2014 Česká republika, Slovenská republika, Mad’arsko, Ukrajina a Polsko. Olomouc: Univerzita Palackého v Olomouci. Retrieved from http://www.hbsc.upol.cz/.

Martin, P., \& McCullagh, J. (2011). Physical Education \& Outdoor Education: complementary but discrete disciplines. AsiaPacific Journal of Health, Sport and Physical Education, 2(1), 67-78. doi: https://doi.org/10.1080/18377122.2011.9730344.

Meredith, J. E., Fortner, R. W., \& Mullins, G. W. (1997). Model of affective learning for nonformal science education facilities. Journal of research in science teaching, 34(8), 805-818. DOI: https://doi.org/10.1002/(SICI)10982736(199710)34:8<805::AID-TEA4>3.0.CO;2-Z

Mužík, V., \& Krejčí, M. (1997). Tělesná výchova a zdraví. Olomouc: Hanex.

Mygind, E. (2007). A comparison between children's physical activity levels at school and learning in an outdoor environment. Journal of Adventure Education \& Outdoor Learning, 7(2), 161-176. doi: https://doi.org/10.1080/14729670701717580.

Mygind, E. (2009). A comparison of childrens' statements about social relations and teaching in the classroom and in the outdoor environment. Journal of Adventure Education and Outdoor Learning, 9(2), 151-169. doi: https://doi. org/10.1080/14729670902860809.

Neill J. T., \& Richards G. E. (1998). Does outdoor education really work? A summary of recent meta- analyses. Australian Journal of Outdoor Education 3(1): 1-9.

Neumann, J. (2000). Dobrodružné hry a cvičení v prírodě. 3rd edition. Praha: Portál.

OEA. (2010). The Freemantle Declaration. Retrieved September 23, 2010, from http://www.outdooreducationaustralia. org.au/

Oost, K., De Vries, B. \& van der Schee, J., A. (2011). Enquiry-driven fieldwork as a rich and powerful teaching strategy school practices in secondary geography education in the Netherlands. International Research in Geographical and Environmental Education, 20(4), 309-325. doi: https://doi.org/10.1080/10382046.2011.619808.

Park, B. J., Tsunetsugu, Y., Kasetani, T., Kagawa, T., \& Miyazaki, Y. (2010). The physiological effects of Shinrin-yoku (taking in the forest atmosphere or forest bathing): evidence from field experiments in 24 forests across Japan. Environmental Health and Preventive Medicine, 15(1), 18-26.

Price, C., Cohen, D., Pribis, P. \& Cerami, J. (2017). Nutrition Education and Body Mass Index in Grades K-12: A Systematic Review. Journal of School Health, 87(9), 715-720. doi: https://doi.org/10.1111/josh.12544.

Rickinson, M., Dillon, J., Teamey, K., Morris, M., Young Choi, M., Sanders, D., \& Benefield, P. (2004). A review of Research Outdoor Learning. National Foundantion for Educational Research: King's College London. 
Shin, W. S. (2007). The influence of forest view through a window on job satisfaction and job stress. Scandinavian Journal of Forest Research, 22(3), 248-253. doi: https://doi.org/10.1080/02827580701262733.

Sigmund, E., \& Sigmundová, D. (2011). Pohybová aktivita pro podporu zdraví dětí a mládeže. Olomouc: Univerzita Palackého v Olomouci.

Smrtová, E., Zabadal, R., \& Kováŕíková, Z. (2012). Za Naturou na túru: metodika terénní výuky. Praha: Apus.

Steele, R. M., Van Sluijs, E. M., Sharp, S. J., Landsbaugh, J. R., Ekelund, U., \& Griffin, S. J. (2010). An investigation of patterns of children's sedentary and vigorous physical activity throughout the week. International Journal of Behavioral Nutrition and Physical Activity 7(1): 88

Steele, R. M., Van Sluijs, E. M., Cassidy, A., Griffin, S. J., \& Ekelund, U. (2009). Targeting sedentary time or moderate-and vigorous-intensity activity: independent relations with adiposity in a population-based sample of 10-y-old British children. The American journal of clinical nutrition, 90(5), 1185-1192.

Strong, W. B., Malina, R. M., Blimkie, C. J., Daniels, S. R., Dishman, R. K., Gutin, B., ... \& Rowland, T. (2005). Evidence based physical activity for school-age youth. The Journal of Pediatrics, 146(6), 732-737. doi: https://doi.org/10.1016/j. jpeds.2005.01.055

Svobodová, H., Mísařová, D., \& Hofmann, E. (2016). Analýza školních vzdělávacích programů ve vztahu k terénní výuce. In A. Nováček (Ed.). Proceedings from:Výroční konference České geografické společnosti Geografické myšlení jako atkuální společenská výzva (pp. 292-302). České Budějovice: Jihočeská univerzita v Českých Budějovicích.

Svobodová, H., Mísařová, D., Durna, R., \& Hofmann, E. (2019). Geography Outdoor Education from the Perspective of Czech Teachers, Pupils and Parents. Journal of Geography, 119(1), 32-41. doi: https://doi.org/10.1080/00221341.2019.1694055

Thorburn, M., \& Allison, P. (2010). Are we ready to go outdoors now? The prospects for outdoor education during a period of curriculum renewal in Scotland. The Curriculum Journal, 21(1), 97-108. doi: https://doi.org/10.1080/09585170903560824

Trávníček, M., Svobodová, H., \& Durna, R. (2018). Assessment of pupils' physical activity during diverse types of teaching lessons. Studia Sportiva (12)1, 141-148. doi: http://dx.doi.org/10.5817/StS2018-1-16

VCAA. (2005). Outdoor and Environmental Studies, Victorian Certificate of Education Study Design. Melbourne: Victorian Curriculum and Assessment Authority.

Vlček, P., Resnik-Planinc, T., Svobodová, H., \& Clausen, S. W. (Eds.). (2016). Integrating Physical Education and Geography: A Case Study of the Czech Republic, Slovenia and Denmark. Brno: Masarykova univerzita.

Waite, S. (2009). Outdoor learning for children aged 2-11: Perceived barriers, potential solutions. Proceedings from: Fourth International Outdoor Education Research Conference (pp. 15-18). Victoria: La Trobe University.

Wareham, N. J., van Sluijs, E. M., \& Ekelund, U. (2005). Physical activity and obesity prevention: a review of the current evidence. Proceedings of the Nutrition Society, 64(2), 229-247. doi: 10.1079/pns2005423

Yang, D., Wang, Z., Xu, D., \& Deng, Z. (2014). A small-scale survey of the views and attitudes of junior high school teachers in China toward geographical fieldwork. International Research in Geographical and Environmental Education, 23(3), 197-212. doi: https://doi.org/10.1080/10382046.2014.927171 